\title{
FAMILIAL INCIDENCE OF RHEUMATOID ARTHRITIS AND ACUTE RHEUMATISM IN 100 RHEUMATOID ARTHRITICS.
}

\author{
BY \\ R. W. BARTER \\ Department of Physical Medicine, West Hertfordshire Hospitals Group
}

(RECEIVED FOR PUBLICATION OCTOBER 23, 1951)

It is comparatively rare in clinical medicine to encounter a condition which can be shown to be inherited as a simple Mendelian gene. As Crew (1947) pointed out, the human subject is by no means satisfactory to study from a genetic point of view; his mate is not chosen for him, he matures slowly, he has few offspring, his chromosomes are numerous, and his mutation rate cannot be speeded up with $x$ rays.

The best we can hope to do, in most diseases, is to show whether or not an heredito-familial tendency is involved. The final picture is modified partly by the powers of penetration of a gene or the modifying influence of other genes, but chiefly by the incalculable effect of environment factors. In those conditions where such a tendency can be shown to exist it is important to establish it and, conversely, to disprove it where absent. This will assist us in our understanding of the aetiology, diagnosis, and prognosis.

Our knowledge of the aetiology of rheumatoid arthritis remains imperfect. The report by the Scientific Advisory Committee of the Empire Rheumatism Council (1950) is probably the most exhaustive clinical investigation on this subject ever undertaken in Great Britain. The results were reached after careful analysis of the case histories of 532 patients and 532 controls. Investigations into a large number of factors commonly believed to influence the onset of rheumatoid arthritis produced largely negative results.

However, in the case of familial factors, the results obtained lend support to the view that these are of aetiological significance. 7 per cent. of the fathers of patients as opposed to 3 per cent. of the fathers of controls suffered from arthritis; 15 per cent. of the mothers of patients as opposed to 9 per cent. of the mothers of controls suffered from arthritis; of 2,151 brothers and sisters of patients, $82(3.8$ per cent.) had arthritis, and of 2,143 brothers and sisters of controls, $38(1 \cdot 8$ per cent.) had arthritis. These figures are considered to be statistically significant. However, the report adds:

The relatively low incidence of a family history of arthritis and the greater likelihood of the patients remembering relatives afflicted with the disease as compared with the controls necessitates withholding any final conclusions on the matter until further investigations have been undertaken. 


\section{Present Investigation}

I considered that it would be worth while to study the family histories of a series of rheumatoid arthritics in relation to rheumatoid arthritis and acute rheumatism. If a family history of arthritis is recorded, cases of osteo-arthritis and gout are presumably included. The former is generally attributed to a degenerative process either secondary to trauma, skeletal abnormality, or infection, or due to senile changes, though it may be argued that an inherited weakness of joint structure is present. The relationship of gouty arthritis to rheumatoid remains obscure. On the other hand, rheumatoid arthritis is an active disease process, with a tendency to exacerbations and remissions which are often spontaneous. (Hench, 1949, estimated that striking remissions are only obtained in 15 per cent. of cases as a result of treatment-rest, physical therapy, gold, etc.but occur in 60-90 per cent. of cases during jaundice or pregnancy.) Clinical observation suggests that this disease bears a close relationship to acute rheumatism. This may be inferred by the close similarity between the histology of the nodules in the two conditions. Dawson (1933), comparing subcutaneous nodules in rheumatic fever and rheumatoid arthritis, considers that:

These studies . . . lend further support to the conception that rheumatic fever and rheumatoid arthritis are intimately related and possibly different responses of affected individuals to the same aetiological agent.

Furthermore, a considerable number of cases develop acute rheumatism, which is followed directly, or after a latent period, by the development of polyarthritis indistinguishable from rheumatoid arthritis. Other cases are seen with evidence of rheumatic carditis and rheumatoid arthritis in which a history of acute rheumatism may or may not be given ( 8 per cent. of the cases in this series were recorded as having suffered from acute rheumatism, or as having definite evidence of rheumatic heart disease). Finally, both conditions are known to respond to cortisone and ACTH, and I hope to show that there exists in certain families a tendency to develop either rheumatoid arthritis or acute rheumatism.

Rheumatoid and osteo-arthritis are clearly divided into two broad groups in the classification of arthritis suggested by a Scientific Committee of the Royal College of Physicians (1934). Acute rheumatism is put into a separate category in this classification.

\section{Material}

Patients Examined.-One hundred unequivocal cases of rheumatoid arthritis have been studied. All cases exhibited the typical symmetrical joint involvement affecting chiefly the small peripheral joints. Routine investigations included $x$ rays of the most affected joints, estimations of the blood sedimentation rate, blood uric acid, and Wassermann reaction, and any other special investigations which were indicated. There was otherwise no selection of cases. 81 per cent. of the cases studied were females, and 19 per cent. males. The proportion of females is higher than in most series, and is probably accounted for by the fact that women tend to come to clinics more regularly than men, especially 
when the latter have to take time off from work. Thus, when cases are recorded as they attend the.clinics, a rather higher proportion of female patients is recorded than is justified by the true sex distribution. The mean age of the patients, when first seen, was 43 for males and 49 for females. The difficulty in fixing any exact date of onset in many cases makes an accurate estimate of the mean age of onset impossible.

In any investigation of this kind a certain number of cases in the families of cases and controls are inevitably missed, either through the persons being unaware of the existence of affected members in their families, or through doubt as to the exact nature of the disease. Although the Report of the Empire Rheumatism Council mentions the possibility that patients may be more likely to remember afflicted members of their families, it does not seem probable that the error from this cause is significant. Arthritis of any severity is such a striking disease that controls will probably be quite as likely as patients to know of its occurrence in their families. Acute rheumatism is not generally connected with arthritis by the lay public, and rheumatoid arthritics are unlikely to have any special knowledge of its occurrence in their families. In the few cases recorded in grandparents very special care was taken to ensure that only true rheumatoid cases were included. Naturally many cases must have been missed, and many cases of arthritis in grandparents were mentioned in which no exact diagnosis could be made. In 33 cases occurring in families of patients and controls the diagnosis of acute rheumatism (as shown by the presence of rheumatic heart disease) or rheumatoid arthritis was checked by personal observation, either in the home or clinic. In a further 21 cases the diagnosis was confirmed by a medical practitioner with knowledge of the case. In the remaining 52 cases no such check was possible, and the patient's history (or in some cases the history of a parent) had to suffice. The question "What type of arthritis?" was asked. Only when the patient was able to state that it was rheumatoid arthritis, and subsequent questioning made this diagnosis seem highly probable, was the case included. In the case of acute rheumatism little ambiguity is possible.

Controls.-One hundred control cases were selected, chiefly from patients admitted for treatment for traumatic conditions and for abdominal surgery. Any person who gave a history of " rheumatism ", or arthritis of any sort, was excluded. For each patient, a control was selected of the same sex, and within 5 years of the same age.

Some of the family histories of controls were not without interest. One lady, aged 37, had nursed her paternal grandfather and her paternal grandmother who were both sufferers from rheumatoid arthritis. In spite of this family history from both sides, only one of her father's four sisters had developed rheumatoid arthritis, and no other member of the family had suffered from arthritis or acute rheumatism. Another lady, aged 35, gave a history of rheumatoid arthritis affecting her maternal grandmother; her mother's generation had escaped, but she had two brothers and two sisters affected with the disease, though she had escaped herself.

One control gave a history of rheumatoid arthritis in her mother and in one sister; another a history of rheumatoid arthritis in her grandmother and of rheumatic fever in her brother, and another of rheumatic fever in one brother and one sister. The other eighteen cases of rheumatoid arthritis or acute rheumatism recorded in the family histories of controls were scattered singly over the whole group.

One lady, aged 48, gave an entirely negative personal history. Her father, however, had had rheumatic fever and had died of rheumatic heart disease, and one brother had suffered from rheumatic fever. On closer questioning she admitted to a short attack of chorea as a girl, and an examination revealed a mitral lesion in the heart, which had previously not been suspected. She was accordingly excluded from the control group, but the case serves to show that help may be obtained from the family history when rheumatic carditis is suspected. 


\section{Analysis of Cases and Comparison with Controls}

Table I gives the incidence of acute rheumatism and rheumatoid arthritis in the families of cases and controls.

TABLE I

INCIDENCE OF RHEUMATIC DISEASE

\begin{tabular}{|c|c|c|c|c|c|c|}
\hline \multirow{2}{*}{ Family Relationship } & \multicolumn{3}{|c|}{ Cases } & \multicolumn{3}{|c|}{ Controls } \\
\hline & Total & No. Affected & $\%$ & Total & No. Affected & $\%$ \\
\hline $\begin{array}{lcc}\text { Grandparents } & \ldots & \ldots \\
\text { Fathers .. } & \ldots & \ldots \\
\text { Mothers } & \ldots & \ldots \\
\text { Uncles and } & \text { Aunts } & \ldots \\
\text { Brothers } & \ldots & \ldots \\
\text { Sisters .. } & \ldots & \ldots\end{array}$ & $\begin{array}{l}400 \\
100 \\
100 \\
470 \\
164 \\
174\end{array}$ & $\begin{array}{r}6 \\
5 \\
13 \\
9 \\
14 \\
27\end{array}$ & $\begin{array}{l}1 \cdot 5 \\
5 \\
13 \\
1 \cdot 9 \\
8 \cdot 5 \\
15 \cdot 5\end{array}$ & $\begin{array}{l}400 \\
100 \\
100 \\
454 \\
173 \\
170\end{array}$ & $\begin{array}{r}4 \\
2 \\
8 \\
3 \\
5 \\
10\end{array}$ & $\begin{array}{l}1 \\
2 \\
8 \\
0 \cdot 66 \\
2 \cdot 9 \\
5 \cdot 9\end{array}$ \\
\hline Total & 1,408 & 74 & $5 \cdot 3$ & 1,397 & 32 & $2 \cdot 3$ \\
\hline
\end{tabular}

A higher proportion of cases is recorded among parents, brothers, and sisters, than among more distant relatives. This is probably due to greater accuracy in the histories relating to close relations, and to the fact that a domiciliary visit may provide confirmation of a doubtful history in this group, whereas grandparents, uncles, and aunts are less readily available.

The incidence in females is greater than in males, as we should expect, and in all groups the incidence is greater in the families of patients than in those of controls. If we confine ourselves to the study of parents, brothers, and sisters only, a much higher proportion of cases is recorded and the discrepancy between patients and controls is more marked.

Of 538 members of the families of patients there were 59 (11 per cent.) affected members.

Of 543 members of the families of controls there were 35 (4.6 per cent.) affected members.

Cases of acute rheumatism or rheumatoid arthritis in nephews, nieces, and sons, or daughters were of course quite often mentioned by patients, but little accuracy is possible when dealing with more distant relatives. Furthermore, a study of the younger age groups does not assist us materially. Occasional cases of acute rheumatism will be found, but not many will have had time to develop rheumatoid arthritis.

The familial incidence of rheumatoid arthritis and acute rheumatism is again demonstrated by a study of the distribution of cases among the families of patients and controls (excluding controls with negative family histories, i.e. 77 control families). Thus we have 123 families; 100 families of cases and 23 families of controls, with affected members. Among these 123 families there were 206 affected members, 106 among the families of patients and controls, and the original 100 cases. Table II gives the distribution of affected members: 
TABLE II

DISTRIBUTION OF AFFECTED MEMBERS OF FAMILIES

\begin{tabular}{c|c|ccc}
\hline No. of Cases in Family & No. of Families & \multicolumn{3}{|c}{ Total No. of Cases } \\
\hline 7 & 1 & 7 \\
5 & 1 & 67 & $32 \cdot 5 \%$ \\
4 & 13 & 16 & 67 & \\
3 & 35 & & 70 & $34 \%$ \\
\hline 2 & 69 & 69 & $33 \cdot 5 \%$ \\
\hline 1 & 13 & & & \\
\hline
\end{tabular}

On these figures, we may conclude that we may expect a family history of rheumatoid arthritis or acute rheumatism affecting more than two members of the family in one-third of rheumatoid arthritis patients, in one-third there will be one other affected member, and in one-third the family history will be negative.

As the proportion of affected members is higher in the families of patients in nevery group studied, arithmetical tests of significance were not considered to be of great importance.

It is not suggested that final conclusions have been reached, but it is hoped that the above figures may help to establish as a scientific fact that in certain families there exists an heredito-familial tendency towards the development of acute rheumatism or rheumatoid arthritis, and further investigations would be of great interest.

\section{Discussion}

Selye (1950), with his conception of a "General Adaptation Syndrome ", attempts to show that a variety of diseases, including rheumatoid arthritis, arise as a result of the body's failure to adapt itself to various stresses. Agents producing stress can act specifically, producing specific injuries, and non-specifically, producing the "Alarm Reaction" (i.e. tissue catabolism, hypoglycaemia, gastro-intestinal erosions, discharge of secretory granules from the adrenal cortex, and haemoconcentration). During the stage of resistance these manifestations disappear or are actually reversed. Should the body become incapable of further resistance a state of exhaustion is reached and these manifestations may reappear. The failure of the body to adapt itself to non-specific local or systemic injuries may result in the appearance of various stress diseases, and exactly which disease appears in a given individual is due to conditioning factors such as heredity, diet, or previous exposure to stress.

Selye's theory assumes that an individual's power of adaptation is a finite quantity greatly dependent upon genetic factors, and our present clinical observations on the heredito-familial tendency to "rheumatic" diseases in certain families accords well with this theory. We may assume, if we accept Selye's theory, that individuals in such families succumb to rheumatoid arthritis and acute 
rheumatism after exposure to "stressors" (i.e. agents producing both stress and specific actions) more easily than normal individuals through an hereditary weakness in their adaptation mechanism.

Kendall, in his Heberden Oration (1951), points out that rheumatoid arthritis " is not an endocrine disease in the usual sense of the term". Patients with Addison's disease are not particularly liable to develop rheumatoid arthritis, and there is no evidence that cortisone is not produced in normal amounts in rheumatoid arthritics.

After discussing other possible causes, such as imbalanced production of cortisone and the amorphous fraction, or the production of a rheumatogenic agent by the adrenal cortex, Kendall tends to the view that a hypersensitivity state may underlie rheumatoid arthritis. (He later points out that rheumatoid arthritis and rheumatic fever " are not far separated in their nature and in their response to cortisone "). If the diseases are, in fact, hypersensitivity reactions to a foreign protein, cortisone might act either by modifying its rate of production, or by protecting the tissues from the effect of the products of this antigen-antibody reaction, as it has been shown to do in many other conditions.

I should like to carry this line of thought a step further. We know that in certain families there exists a marked constitutional tendency towards the development of certain hypersensitivity states; asthma, hay fever, and urticaria are common examples, though of course many cases of these maladies are seen in which there is no relevant family history. In these families the effects of the products of an antigen-antibody reaction are most marked in certain tissues, the bronchial or nasal mucosa, or the skin and subcutaneous tissues, as the case may be.

May it not be that in certain families there is a constitutional tendency to react through the medium of the synovial membranes? We might then explain the action of cortisone as modifying the effect of such a reaction. In this connection it is perhaps interesting to note that the antihistamine drugs have not proved effective in treating asthma, whereas cortisone produces a dramatic effect in most cases.

Meanwhile, from the practical point of view, a careful family history should always be taken in cases of suspected rheumatoid arthritis, especially in patients in the pre-arthritic stage when diagnosis is difficult. When several members of the family have suffered from rheumatoid arthritis or acute rheumatism, the onset of such prodromal symptoms as joint or muscle pains, migrant joint swellings, or paraesthesiae, in an individual are particularly likely to indicate the onset of rheumatoid arthritis. Such a family history may also be helpful in establishing the diagnosis in cases of suspected rheumatic carditis and valvular disease of the heart.

\section{Summary}

The familial incidence of rheumatoid arthritis and acute rheumatism was compared in 100 rheumatoid arthritics and 100 controls.

The incidence of these diseases was found to be more than twice as frequent 
in the families of patients as in those of the control group: $5 \cdot 3$ per cent. and $2 \cdot 3$ per cent. respectively, when grandparents, parents, uncles, aunts, brothers, and sisters were included; 11 per cent. and 4.6 per cent. respectively, when only parents, brothers, and sisters were included.

From the figures obtained in this series, it is concluded that approximately one-third of rheumatoid arthritics will give a family history of rheumatoid arthritis or acute rheumatism in two or more members of their families (as many as seven affected members were recorded in one family of sixteen); approximately one-third will give a history of one affected member; the remaining one-third will give a negative family history.

It is suggested that an heredito-familial tendency towards the development of acute rheumatism or rheumatoid arthritis occurs in certain families.

The occurrence of such a constitutional tendency is discussed in relation to Selye's "General Adaptation Syndrome" and Kendall's view that a hypersensitivity state may underlie rheumatoid arthritis: as regards the former, certain individuals may have an hereditary weakness in their adaptation mechanism; as regards the latter, it is suggested that certain individuals may have a constitutional tendency to react to the effects of the products of an antigen-antibody reaction through the medium of the synovial membranes.

The cases in this series were under the care of Dr. J. Shulman, Physician-in-Charge, Department of Physical Medicine, Coventry and Warwickshire Hospital, and I am most grateful for his permission to publish them.

\section{REFERENCES}

Crew, F. A. E. (1947). “Genetics in relation to Clinical Medicine.” Oliver and Boyd, Edinburgh. Dawson, M. H. (1933). J. exp. Med., 57, 845.

Hench, P. S. (1949). Annals of the Rheumatic Diseases, 8, 90.

, Kendall, E. C., Slocumb, C. H., and Polley, H. F. (1949). Proc. Mayo Clin., 24, 181.

Kendall, E. C. (1951). " Heberden Oration, 1951." Brit. med. J., 2, 1295, also Annals of the Rheumatic Diseases, 10, 453.

Lewis-Faning, E. (1950). Scientific Advisory Committee, Empire Rheumatism Council, " Report on an Enquiry into the Aetiological Factors associated with Rheumatoid Arthritis ". Annals of the Rheumatic Diseases, 9, Suppl.

Report on Classification and Nomenclature of the Committee of the Royal College of Physicians, 1934. Reports on Chronic Rheumatic Diseases, No. 1. Lewis, London.

Selye, H. (1950). " "Heberden Oration, 1950." Brit. med. J., 1, 1362, 1383, also Annals of the Rheumatic Diseases, 9, 246.

La fréquence de l'arthrite rhumatismale et du rhumatisme articulaire aigu dans les familles des 100 arthritiques rhumatisants

\section{RÉSUMÉ}

La fréquence familiale de l'arthrite rhumatismale et du rhumatisme articulaire aigu chez 100 arthritiques rhumatisants fut comparée à celle chez 100 témoins.

On trouva que les affections rhumatismales étaient deux fois plus fréquentes dans les familles des malades que dans celles des témoins: 5,3 et 2,3 pour cent respectivement, quand il s'agissait de grands-parents, parents, oncles, tantes, frères, et soeurs; 11 et 4,6 pour cent respectivement, quand on ne considéra que les parents, les frères, et les soeurs.

D'après les chiffres obtenus, on peut conclure qu'un tiers environ d'arthritiques rhumatisants présente des antécédents familiaux d'arthrite rhumatismale ou de rhumatisme articulaire aigu frappant deux parents ou plus (dans une famille de seize on trouva sept affectés): dans un autre tiers environ un membre se trouve affecté, et le dernier tiers n'a pas d'antécédents familiaux. 
On suggère que certaines familles ont une tendance hérédo-familiale à contracter le rhumatisme articulaire aigu ou l'arthrite rhumatismale.

On discute l'existence d'une telle tendance à la lumière du " syndrome d'adaptation générale " de Selye et de l'opinion de Kendall qu'un état d'hypersensibilité forme la base de l'arthrite rhumatismale: si on acceptait la théorie de Selye, le mécanisme d'adaptation de certaines personnes souffrirait d'une faiblesse héréditaire, et si on suivait celle de Kendall, il faudrait admettre l'existence chez certains sujets d'une tendance constitutionnelle à réagir contre les produits de la réaction entre l'antigène et l'anticorps par l'intermédiaire des membranes synoviales.

\section{La incidencia familiar de la artritis reumatoide $y$ del reumatismo articular agudo en 100 artritícos reumatoides}

\section{SUMARIO}

Se comparó la incidencia de la artritis reumatoide y del reumatismo articular agudo en las famillas de 100 artríticos reumatoides y en las de 100 testigos.

Resultó que las afecciones reumáticas ocurrían con una frecuencia más de dos veces mayor en las famillas de los enfermos que en las de los testigos: 5,3 y $2,3 \%$ respectivamente al tratarse de abuelos, padres, tíos y hermanos de ambos sexos; 11 y $4,6 \%$ respectivamente, tomando en cuenta sólo á los padres y hermanos de ambos sexos.

Según las cifras obtenidas, se puede concluir que cerca de una tercera parte de los casos de artritis reumatoide o de reumatismo articular agudo tendrán antecedentes familiares de artritis reumatoide o de reumatismo articular agudo afectando dos o más parientes (en una familia de 16: personas hubo siete afectados !): en otra tercera parte aproximadamente habra un miembro afectado y en la restante tercera no habrá antecedentes familiares.

Se sugiere que ciertas familias tienen una tendencia heredo-familiar a contraer la artritis reumatoide o el reumatismo articular agudo.

Se discute la existencia de tal tendencia en relación con el " síndrome de adaptación general " de Selye y con la opinión de Kendall, según la cual un estado de hipersensibilidad formaría la base de la artritis reumatoide: si se aceptara la teoría de Selye, el mecanismo de adaptación de ciertas personas sufriría de una debilidad hereditaria; al seguir la de Kendall, habría que admitir la existencia en ciertos sujetos de una tendencia constitucional a reaccionar contra los productos del encuentro entre el antigeno y el anticuerpo por medio de las membranas sinoviales. 